\title{
Modern Slavery in Indonesia : \\ Study Case of Maritime Slavery in Benjina \\ Kabupaten Kepulauan Aru Maluku
}

\author{
Anastazia N Wattimena \\ Universitas Muhammadiyah Yogyakarta \\ anastasyawattimena@gmail.com
}

\begin{abstract}
The case of maritime slavery that took place in Benjina, significance unpopular, and isolated area in the easternmost part of Indonesia shook the world. Hundreds of foreign shipmen, seafarers, were found enslaved for years. Forced by the captains of Thailand ships vessels from PT. Pusaka Benjina Resources to work long and extra hours without being given any appropriate payments and food along the way. This paper is a qualitative type of research using secondary data from books, journals, articles, both online and paper-based, to gather all related information. This paper also used the theory of modern slavery as a management practice from Andrew Crane to analyze the pushing factors of this slavery case. Hoping that the same situation will no longer happen in the future. Since slavery in the fishing industry has happened in so many sea-based countries in the world, including Indonesia.
\end{abstract}

Keywords: slavery, maritime industry, foreign shipmen, Benjina

\begin{abstract}
Abstrak
Kasus perbudakan maritim yang terjadi di Benjina, wilayah yang tidak populer, dan terisolir di bagian timur Indonesia mengguncang dunia. Ratusan awak kapal asing, pelaut, ditemukan diperbudak selama bertahun-tahun. Dipaksa oleh kapten kapal Thailand kapal dari PT.Pusaka Benjina Resources untuk bekerja berjam-jam dan ekstra tanpa diberikan pembayaran dan makanan yang sesuai di sepanjang jalan. Makalah ini adalah jenis penelitian kualitatif menggunakan data sekunder dari buku, jurnal, artikel, baik online dan berbasis kertas, untuk mengumpulkan semua informasi terkait. Makalah
\end{abstract}


ini juga menggunakan teori perbudakan modern sebagai praktik manajemen dari Andrew Crane untuk menganalisis faktor-faktor pendorong dari kasus perbudakan ini. Berharap bahwa situasi yang sama tidak akan terjadi lagi di masa depan. Sejak perbudakan di industri perikanan telah terjadi di banyak negara berbasis laut di dunia, termasuk Indonesia.

Kata kunci: perbudakan, industri maritim, kapal asing, Benjina

\section{INTRODUCTION}

Associated Press in March 2015 published this case regarding hundreds of seafarers who happened to be slaves in fishing ships from a company called PT. Pusaka Benjina Resources (McDowell, Manson, \& Mendoza, 2015). the exploitation occurred both in the sea and land, the land of Benjina, a small village located in one of the easternmost parts of Indonesia.

According to the investigation of AP and extended interviews between the International Organization of Migration (IOM Indonesia) and all the slavery victims. the captain of the ship enslaved all foreign ship crews, and not just in one ship but in almost all the vessels owned by PT. PBR. the victims were all beaten by the big fishtail. They were in a cage where they only got curry to survive every day. They had to work 18-20 hours per day. Whenever they were tired and complained, the captain would beat them. Some of them died in the Arafura Sea. Some of them were buried in Benjina, and to cover the trails. They changed the name of ship crews when buried to hide the death (McDowell, Manson, \& Mendoza, 2015).

For the first time, AP found the case long before. There was an investigation held by LPN (Labors Right Promotion Network) and SAC (Seafarers Action Centre) in corporation with AP and Channel 3 Thailand regarding their fishing vessels, especially the ones which traveled to Indonesia. Due to deep suspicion about the human trafficking network, especially involving Thailand, Myanmar, Laos, Cambodia, and Indonesia (Tangprachyakul, 2015).

During 2006-2014, LPN accepted around 128 complaints about seafarers who left Indonesia. Thirty-nine people went back to Thailand, death, and two others 
were disabled. There were neither payment nor compensation for those people (Tangprachyakul, 2015). For that reason, then LPN helped by AP, and other actors decided to have further investigation to Indonesian water regarding those fishermen. Finally, it becomes the starting point for a significant discovery in Benjina a year after.

In the maritime industry, laborers are fragile, trapped in slavery. Fishing labors cost 30\%-50\% of the total fishing costs. Then those costs tend to be cut to minimize total production costs. It makes the company tend to ignore the safety standards of crews or to decrease their payments or even eliminate it at all (Tickler, et al., 2018).

After the case was published, the Indonesia government reacted in specific ways. For instance, the Indonesian government represented by the Ministry of Maritime and Fisheries took the first step by sending teams to investigate further the verdict of slavery as well as helping all the victims, especially in terms of their documents supported by Immigration Ministry.

The second response from the Indonesia government would be extending the moratorium until October 2015 to hold long and detailed investigations throughout the case. They also suspended foreign ships from Indonesia water, especially those who came from Thailand fishing companies (Dillon, 2015).

According to IOM, nearly 550 people were safe from the practice of modern slavery in Indonesia. Based on the Global Slavery Index 2016, Indonesia was in the first place as a country, having the most number of current slavery cases compared to other ASEAN countries (Sindo, 2018).

All the fish, shrimps, and different kinds of seafood captured by slaves come from Thailand. All the fish and shrimp are processed and become canned food sold in big markets in United States such as Wall-Mart, Kroger, and Sysco (Mendoza, US Lets in Thai Fish Caught by Slaves Despite Law, 2015). Hearing the issue of fish products produced by slaves in Indonesia, the US government then passed an act of banning all kinds of fish products captured by slaves and or forced laborers. President Barrack Obama signed House of Resolution 644 on February $24^{\text {th }}$, 2016 (Mendoza, Obama Bans US Imports of Slave-Produced Goods, 2016).

People probably wonder why the issue of slavery even exists in 
this $21^{\text {st }}$ century after a long time. After this practice of slavery banned all over the world since 18 century, but for the record even until the $20^{\text {th }}$ century, chattel slavery still existed in Arabia. Slavery in these days has been quite modernized, meaning that it has many differences than chattel slavery that had happened in the past (Miers, 2011).

If chattel slavery was a possession of someone who can be bought, owned, and sold to another party. Modern slavery has many differences in a point where there is no legal ownership toward the slaves, and how the violence become an ultimate tight between the slaves and slaveholders (Bales, Understanding Global Slavery : A Reader, 2005).

Since the phenomena of slavery come back over time, the author is interested in exploring more, especially regarding the push factors of slavery even occur in the first place.

\section{METHODOLOGY AND THEORY}

This research used secondary data taking from multiple resources like books, journals, websites, as well as an online newspaper. Hopefully, it can give the closest pictures about what happened in Benjina and why it even happened. the author analyzed the factors behind this phenomenon using the theory of modern slavery brought by Andrew Crane. However, the author did not use all five indicators; instead, only two of them. the author believes that those two indicators are enough to give the exact explanation about this new phenomenon in the maritime industry.

\section{Theory of Modern Slavery}

Andrew Crane (2013), with his theory of modern slavery, explains five different indicators enabling the practice of modern slavery as a form of management practice. Those five indicators consist of industrial context, socioeconomic context, geographical context, cultural context, and regulatory context. in this research, the author only will focus on two contexts, which are socio-economic context and regulatory context. the socioeconomic context has several parts. They are poverty and relative poverty, education, and awareness, as well as unemployment (Crane, 2013). Meanwhile, the regulatory context consists of the strength of governance and issue attention.

The author will explain all indicators in the perspectives of the slaves and the Indonesian government to give a concise 
yet comprehensive explanation regarding why the practice of slavery even happens in the east part of Indonesia, especially the kind of maritime slavery.

In his writing, Crane explains that poverty will always be the "push" factors that trap people into slavery. People who live under poverty create opportunities, especially for slave recruiters, where they can be very persuasive to influence the potential laborers. in contrast, the laborers themselves have no better options. Slavery will probably occur in one geographic location if it is perceived to have more extreme poverty compare to another area.

The next indicator will be unemployment, directly linked to poverty. Unemployment situation because of no skills and limited job opportunities, especially if it structurally happens. Those situations are going to make the offer seems so realistic as the family the only option as economic survival choices, specifically if they have no alternative job options and without adequate social protection. in most modern slavery cases, all slaves are victims of deceiving and coercing. They are not well aware of the working arrangements due to lack of education and illiteracy among the target population (Crane, 2013).
The second context will be regulatory, which regarding slavery laws, both national and international levels. in this context, Crane also emphasizes on governance system. How effective the system, how corrupt the system, or how low the maintenance of regional governance system. Thus, it creates the possibilities of slavery to appear quickly.

The two contexts of Crane about the theory of modern slavery could explain the situation in Benjina since 2015.

\section{RESULT AND EXPLANATION}

There are quite progressive developments of research, especially about modern slavery in general. Talking about modern slavery, Kevin Bales, in his book Disposal People, "slavery means that total control of one person by another for the purpose of economic exploitation" (Bales, Disposable People : New Slavery in the Global Economy, 2000). Old slavery may concern color skin, ethnics, race, or religion as the consideration to enslave somebody. However, modern slavery does a different job. Modern slavery focuses on weakness, gullibility, and deprivation despite races and or skin colors. 
The causes of old slavery no longer become causes for modern slavery. According to Bales, the slavery grows best in an extreme poverty situation because the slaveholder can easily predict the pre-social status of slaves target. Second, the slaveholder has to ensure that the cost of keeping a slave is much cheaper than hiring free labor (Bales, Disposable People : New Slavery in the Global Economy, 2000). Slavery happens from the desperation of options, being abandoned, a refuge, being poor, and the homeless to avoid the potency of being enslaved by somebody else. Thirdly, slaves target should not have access for any helps or having any power to defend themselves against violence. Those vulnerabilities make it so hard for slaves to save themselves from the slaveholder.

Old slaves in 1850 may cost almost $\$ 40.000$ in modern money, but now slave worth only a few hundred dollars. This change, of course, has consequences, slaves nowadays are cheaper. It makes them so affordable to have but at the same time disposable, according to Kevin Bales in his book the Slave Next Door (Bales \& Soodalter, the Slave Next Door : Human Trafficking and Slavery in America Today, 2009).
They do not give much money if being sold. Still, they will create thousands of profits from their work and exploitation, especially for industrial slavery or maritime slavery. That is why companies tend to enslave their workers if they have the chance to ensure a significant outcome over smaller costs.

\section{Poverty and Low Education Contribute to Create Opportunity to Enslave People}

The victims of Benjina Slavery cases are mostly coming from countries such as Myanmar, Cambodia, and Laos.

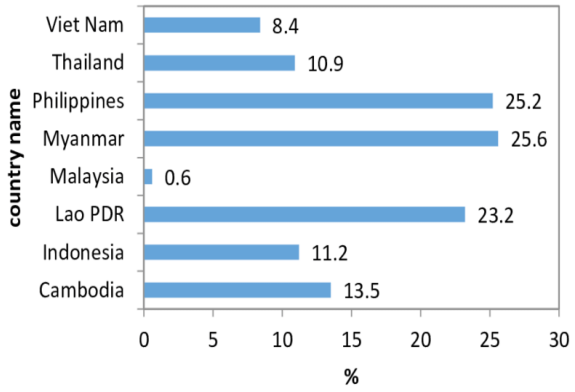

Figure.1

Population Living in Poverty in ASEAN 2014 Based on ADB 2014

(Tien, Ranola.,Jr, \& Thuy, 2017)

Slavery always starts with human trafficking. People living in poverty in developing countries usually become an easy target to be manipulated by the recruiters. the figure above shows the population living under poverty in 2014, and not 
surprisingly, Myanmar, Cambodia, and Laos are on the top lists of countries living under poverty. the problem with having many people living under poverty is that they will be most likely unemployment for so many reasons. They belong to the poor for a reason. They couldn't afford their basic living needs, not to mention they do not have a permanent job, most likely because of no having qualified education or a structured direction into poverty. However, no matter what the reason behind those people living under poverty, being unemployment as well as having low or no education at all make them much more fragile and vulnerable. That vulnerability becomes an opportunity for the recruiters to traffic them to the outside territory, then, in the end, become slaves.

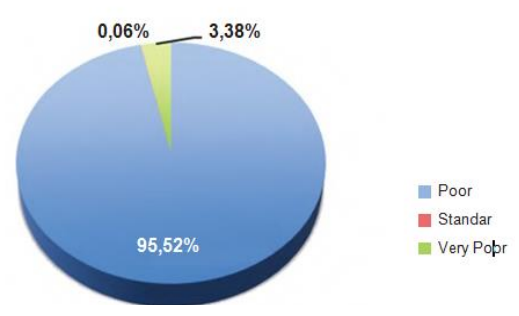

Figure 2.

Financial Situation of Victims Before They Enter Indonesia (KKP

Indonesia, Satgas IUU Fishing Indonesia, IOM Indonesia, \& Universitas Coventry, 2016)
From the figure, the victims identify themselves as either poor or very poor. By feeling that way, they realize that it is so essential for them to have more options for sustained life. One option that seems so potential is migration. Moving to another location or territory that appears to have more choices of job. the recruiters well play this moment. They saw the opportunity and offer help by promising to give an alternative career in other territories as what has happened in most modern slavery cases.

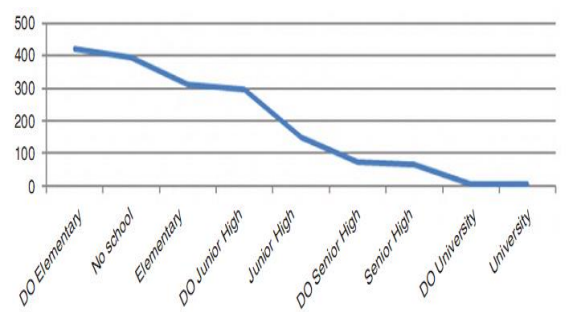

Figure 3.

Level of Education from Foreign Victims of Trafficking sent to Indonesia (KKP Indonesia, Satgas IUU Fishing Indonesia, IOM Indonesia, \& Universitas Coventry, 2016)

Victims of human trafficking sent to Indonesia, especially fishers, are having low education in general. For Crane (2013), it is right from the perspective of the slaveholder. When someone has little knowledge about where they are geographically 
and having no information on access to save themselves as well as they do not communicate well with the foreign language, it will make them hard to get their freedom out of slavery.

\section{a. Myanmar}

After being independent of British colonization in 1948, Myanmar, also known as Burma at the time, had a dictatorship regime for quite a long period since 1962 (Champkin, 2012). the military government seemed so repressive until Myanmar themselves got international sanctions for it. For Min Zing, as he wrote in Foreign Policy magazine, poverty in Myanmar rises not only due to the international sanctions against them, but more importantly, for him, is allocation of Myanmar national budget is imbalanced.

Myanmar government spent $23,6 \%$ ( $\$ 2$ billion) of their federal budget in the military, $1,3 \%$ (\$ 110 million) for health, and for education, they only allocate $4,13 \%$ (\$ 349 million) from their national budget. No wonder if they have quite a significant number of people living under poverty.

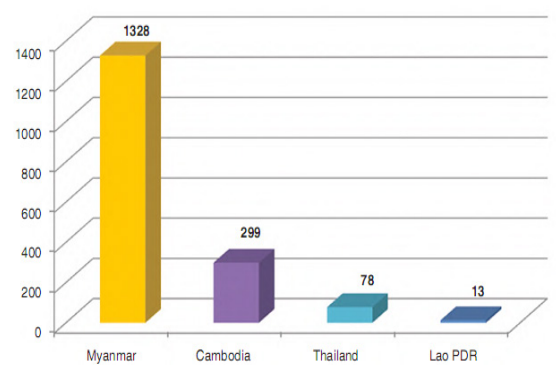

Figure 4.

Nationality of Human Trafficking Victims in Indonesia 2011-2015 (KKP Indonesia, Satgas IUU Fishing Indonesia, IOM Indonesia, \& Universitas Coventry, 2016)

Figure 4. above reflects how many Myanmar citizens become victims of human trafficking. This particular country has been so vulnerable for such a long time, like Thailand, which is already well-known as a place for human trafficking recruiters. Myanmar, on the other hand, has been so famous as forced laborers and slaves supplier.

In 2014, the Thai government reported that there are 224 Myanmar citizens as victims of human trafficking in Thailand (Crime, 2017). It has been a long time connection between Myanmar and Thailand in terms of human trafficking. As time goes by since human trafficking can lead to slavery. Thus, ASEAN should 
probably do a little better to cut the tie between those two countries.

There is no much information regarding the victims from Benjina slave case, especially from the historical background of those victims from Myanmar, but there are two things for sure. First, they are all poor, and second, they are not well-educated. Those two causes make people so vulnerable and do not think much when they accept the offer of working to another location.

\section{b. Cambodia}

Cambodia is infamous for its conflict of Preah Vier temple, which become the most intense conflict between Cambodia and Thailand. However, the author will only focus on the long history of human trafficking lead to slavery-related to both Cambodia and Thailand.

\begin{tabular}{c|c}
\hline \multicolumn{2}{c}{ Official Repatriations from Thailand of } \\
Cambodian Human Trafficking Victims
\end{tabular}

Figure 5.

Human Trafficking from

Cambodia (SIREN Human

Traffickig Data Sheet, 2008)

The data above lists the number of victims of human trafficking that repatriate from Thailand. It seems like both countries have had a long tight relationship in human trafficking either as transit or as a destination. It is not shocking at all that more countries in ASEAN involve in human trafficking since the distance between each country is quite close to each other. Secondly, countries in ASEAN are still developing countries, which have a problem with poverty as well as education access.

Going back to Cambodia, they seem to have an average economic growth from 1998-2018 (8 \%), as World Bank said (The World Bank in Cambodia, 2019). At least not as much severe as Myanmar did, but still, the poverty of its society contributes to human trafficking in ASEAN. There has been quite a dangerous supply chain of human trafficking involving countries in ASEAN.

Cambodian women and girls historically become victims of human trafficking, whether in Thailand or other ASEAN countries. While men as victims increase hugely, especially in the Thailand fishing industry, after the government passed a new Trafficking Law (SIREN Human Traffickig Data Sheet, 2008). 
As a report from the United Nations, they interviewed in Cambodia. Moving and having to immigrate from Cambodia to Thailand is pretty much necessary because of the unavailability of jobs in Cambodia. Thailand has higher wages than Cambodia. It is $20-30 \%$ higher in Thailand than in Cambodia for the same position or job (Crime, 2017). Thus, Thailand is so much attractive for people in their productive ages.

\section{c. Lao PDR}

Lao PDR is having almost the same background as the other fellow countries. Having a lot of experiences regarding social, economic problems after its independence in 1975. Lao PDR has had such difficult times because they passed through a civil war between the Royal Lao Government and Communist Pathet Lao. This country also took part in the Indochina conflict. Despite all former conflicts, Lao PDR is well known as a land-linked country because it has bordered neighbors such as Myanmar, Cambodia, China, Thailand, and Vietnam (About Lao PDR). Such geographic position supposedly gives more advantages to the country, for example, become a trading track connected China and the rest of
ASEAN countries. Providing some sort of disadvantages also becomes the track for human trafficking along with regional ASEAN.

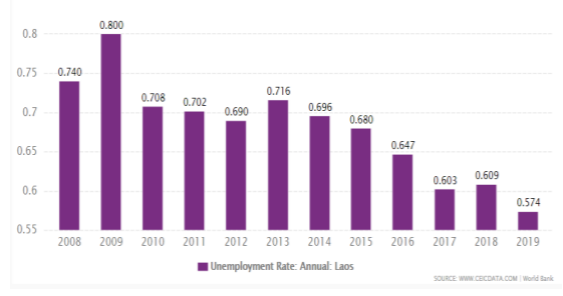

Figure 6.

Unemployment Rate Annually in Lao PDR Sourced World Bank

(Laos Tingkat Pengangguran)

The graphic shows that Lao PDR does not necessarily have such a massive problem of both unemployment and poverty compared to its neighbor, Myanmar. Lao PDR has successfully managed its advantages as a land-linked country to enhance its economy. Further, to minimize the number of poverty.

Both human trafficking and modern slavery in the fishing industry are inevitable reality facing ASEAN. Thailand has a consistency to grow its seafood industry. At the same time, Indonesia acts as a giant supplier for seafood, and the rest of ASEAN member countries trapped in between either as transit location or fall as victims for human trafficking and slavery. 
Bribery Increase the Chances for Slavery

The practice of bribery is not a new trend in worldwide. in almost all aspects of life, we will find the method of corruption lying around everywhere. Legally speaking, it is, of course, trespassing the law to give or accept bribery, but sometimes to smoothing a business, this bribery is necessary. Moving to the case in Benjina 2015, Indonesia's government has a strict regulation, especially about foreign vessels shipping who operate and catching fish in Indonesia water.

For example, Act Number 31 of 2004 about Fishing, article 27 clearly states that every fishing vessel, both local fishing vessels or foreign fishing vessels are obliged to have SIPI Surat Izin Penangkapan Ikan or Fishing License before running their operation. It is a proper and strict regulation (Indonesia, 2004). However, the unavailability of maritime security patrols makes it so hard for monitoring ships that change their flag in the middle of the ocean to avoid making SIPI.

PT. Pusaka Benjina Resources themselves did quite significant bribery to cover their act of slavery. PT. PBR intentionally gave Rp. 37 million each month for local apparatus to maintain their operation (Dugaan Suap, Perbudakan dan Kerajaan Kecil di Benjina, 2015). Therefore, the practice of slavery can occur again for such a long time. According to several victims, they have been in exploitation for almost ten years. Some even got more.

The practice continuously goes on not because people surrounding have no idea. It is because they do not want to tell. Bribery makes them do so. So, it is imperative to build high maintenance security in a location where there are high foreign ship vessels, as well as erasing the possibility of corruption and bribery, especially at the local governance level.

\section{CONCLUSION}

Slavery has been in a ban for years, but it somehow grows and develops in its new form that currently known as modern slavery. This modern slavery is a high performed human exploitation that violates the most significant value of human beings. This type of slavery develops in various areas of a country. One of them is in the maritime and fishing industry. Indonesia is not the only country that has to deal with this issue. People from Indonesia may be 
victims of this maritime slavery somewhere else as well.

This slavery is possible to happen under so many reasons and situations that help it to exist. Two among those various reasons and conditions are poverty, lack of education, the effectiveness of government, and regulation or the rule of law, and corruption, as explained by Crane (2013). This paper may not provide a systemic solution, but it has helped identify the reason behind this slavery practice. Since by knowing the pushing factors, it will help to contribute to creating the best possible solution to against modern slavery.

\section{REFERENCES}

Bales, K. (2000). Disposable People: New Slavery in the Global Economy. Los Angeles California: University of California Press.

Bales, K. (2005). Understanding Global Slavery : A Reader. Los Angeles: University of California Press.

Bales, K., \& Soodalter, R. (2009). the Slave Next Door: Human Trafficking and Slavery in America Today. Los Angeles: University of California Press.
Miguel, C. S. (2011). Enslavement. in J. P. Rodrigues, Slavery in the Modern World: A History of Political, Social, Economic Operation (p. 34). Santa Barbara, California: ABCCLIO, LLC.

Miers, S. (2011). Slavery and Abolition in the 20th Century. in J. P. Rodriguez, Slavery in the Modern World: A History of Political, Social, and Economic Oppression (pp. 3-33). California: ABC-CLIO Press.

Crane, A. (2013). Modern Slavery As A Management Practice: Exploring the Conditions and Capabilities for Human Exploitation. Academy of Management Review, 38(1), 4969.

Tickler, D., Meeuwig, J. J., Bryant, K., David, F., Forrest, F. A., Gordon, E., et al. (2018). Modern Slavery and the Race to Fish. Nature Communications, 1-9.

Tien, N. D., Ranola.,Jr, R. F., \& Thuy, P. T. (2017). Potential Impact of the REDD+ Program on Poverty Reduction in Nghe An Province, Vietnam. Forests Vol. 8 (376), 2-18.

(2008). SIREN Human Traffickig Data Sheet. United Nations Inter-Agency Project on 
Human Trafficking (UNIAP): Phase III.

KKP Indonesia, Satgas IUU Fishing Indonesia, IOM Indonesia, \& Universitas Coventry. (2016). Laporan Mengenai Perdagangan Orang, Pekerja Paksa, dan Kejahatan Perikanan dalam Industri Perikanan Indonesia. Indonesia: International Organization of Migration.

McDowell, R., Manson, M., \& Mendoza, M. (2015). AP Investigation : Are Slaves Catching the Fish You Buy? . Associated Press.

Tangprachyakul, P. (2015, Oktober, 21). LPN.Files. Wordpress. Retrieved January 4, 2020, from LPN: https://lpnthailand.files. wordpress.com $/ 2015 / 08 /$ thespecial-report-on-operationssaving-workers-in-fishingboats-from-indonesia.pdf

Dugaan Suap, Perbudakan dan Kerajaan Kecil di Benjina. (2015, April 8). Retrieved January 16, 2020, from Detik News: https://news.detik.com/ berita/2881061/dugaan-suapperbudakan-dan-kerajaankecil-di-benjina?ntprofil=

The World Bank in Cambodia. (2019, September 25). Retrieved January 11, 2020, from World
Bank: https://www.worldbank. org/en/country/cambodia/ overview

About Lao PDR. (n.d.). Retrieved January 15, 2020, from UNDP Lao PDR: https://www.la.undp. org/content/lao_pdr/en/home/ countryinfo.html

Champkin, J. (2012, April 17). Burma: How Poor? How Repressive? Retrieved January 10, 2020, from Significance: https://www.statslife.org.uk/ social-sciences/1586-burmahow-poor-how-repressive

Crime, U. N. (2017). Trafficking in Person from Cambodia, Lao PDR, and Myanmar to Thailand. Bangkok: UNODC.

Dillon, P. (2015, Maret, 8). Over 500 New Human Trafficking Victims Identified in Indonesia Since Benjina "Slave Fisheries" Exposed. Retrieved January 5, 2020, from IOM UN Immigration: https://weblog.iom.int/over500-new-human-traffickingvictims-identified-indonesiabenjina-\%E2\%80\%98slavefisheries\%E2\%80\%99-exposed Indonesia, P. R. (2004). UndangUndang Nomor 31 Tahun 2004 Tentang Perikanan. Retrieved January 16, 2020, from DPR: 
http://www.dpr.go.id/dokjdih/ document/uu/32.pdf

Laos Tingkat Pengangguran. (n.d.).

Retrieved January 15, 2020, from CEIC: https://www. ceicdata.com/id/indicator/laos/ unemployment-rate

Mendoza, M. (2015, April 22). US Lets in Thai Fish Caught by Slaves Despite Law . Retrieved January 5, 2020, from Associated Press: https://www.ap.org/explore/ seafood-from-slaves/us-letsin-thai-fish-caught-by-slavesdespite-law.html

Mendoza, M. (2016, February 25). Obama Bans US Imports of Slave-Produced Goods. Retrieved January 6, 2020, from Associated Press: https:// www.ap.org/explore/seafoodfrom-slaves/Obama-bans-USimports-of-slave-producedgoods.html
Sindo, K. (2018, February 21). Negara Dengan Pebudakan Modern Terbanyak. Retrieved January 5, 2020, from Sindo News: https:// international.sindonews. $\mathrm{com} / \mathrm{read} / 1283606 / 45 /$ negara-dengan-perbudakanmodern-terbanyak - d i dunia-1519112527 